\title{
How Does Historical Faith Complement Immanuel Kant's Philosophy of Religion?
}

\author{
- Tomasz Kupś -
}

\begin{abstract}
A shift away from exclusionary moral reductionism can be discerned in modern interpretations of Kant's philosophy of religion. Consequently, at least since the 1970s, historical faith has been appreciated as a necessary and desirable element of Kant's philosophy of religion. One of the reasons prompting Kant to include historical faith in his system of the philosophy of religion is what commentators on Kant's philosophy call the 'moral gap' as there is a disproportion between the limited competence of man as a natural being and moral goals that seem unattainable. For the believer, the content of historical faith offers a real solution to the disproportion between his limitations as a natural being and the goals set for him by practical reason. For the believer, the 'moral gap' is not just a theoretical problem, but an existential challenge whose solution lies beyond his own limited competence. In this article, I consider whether historical faith can also provide a theoretical supplement to the picture of one's own life. If so, then the content of historical faith may also prove important for the non-believer.
\end{abstract}

Keywords: Immanuel Kant, historical faith, pure rational religion, "deep structure", "moral gap", philosophy of religion, ethics.

Published online: 31 July 2021

\section{Introduction}

Interpretations of Kant's philosophy of religion vary in terms of how they understand the meaning of historical faith. Traditional interpretations have typically led to a presentation of Kant's philosophy of religion in the spirit of exclusionary moral reductionism. In recent years, however, propositions have appeared to soften the traditional interpretations based on moral rigorism and deontologism. An example of the new interpretation can be found in the texts of Stephen R. Palmquist questioning the extreme reductionism of some interpreters of Kant's philosophy. ${ }^{1}$ I share Palmquist's conviction that to disregard historical faith in its entirety as superstition would be unwise and would reflect badly

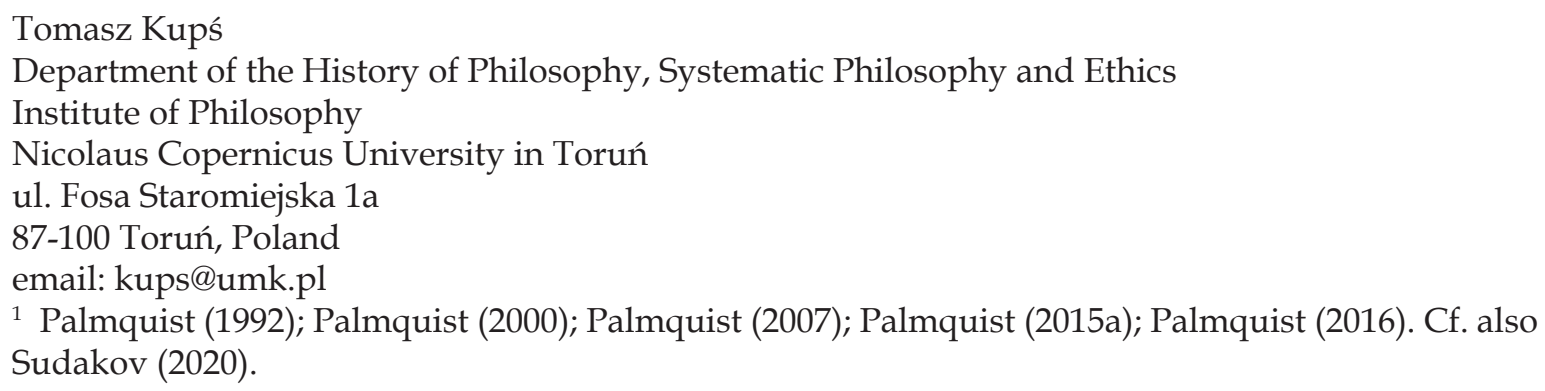


on whoever advocated such a position. Kant not only does not reject historical faith, but he even makes it an indispensable component of his philosophy of religion. The indispensability of historical faith in Kant's philosophy of religion is argued by Palmquist as needed because of the 'teleological incompleteness' of morality. Humans need some form of historical faith because abandoning its promises would make the goal of a good life virtually impossible for a finite being such as man. This is because historical faith provides us with the 'theoretical complement' necessary to think of practical life goals as achievable. On the one hand, historical faith offers us proven solutions (practical ideas) which, from the theoretical perspective, we must treat as something that is 'given' (revealed). On the other hand, practical ideas constrain us when it comes to the way we imagine the 'completion' of moral concepts from the perspective of goals. The restriction of the way practical goals are formulated by the content of historical faith is paradoxically beneficial, because it protects us from the danger of turning practical philosophy into a completely arbitrary product of human creativity.

The answer to the question concerning the relationship between ethics and religion in Kant's philosophy is far from unambiguous. In the Critique of Practical Reason Kant wrote that "the moral law leads through the concept of the highest good, as the object and final end of pure practical reason, to religion, that is, to the recognition of all duties as divine commands, not as sanctions - that is, chosen and in themselves contingent ordinances of another's will" (KpV, AA 05:129), ${ }^{2}$ but only five years later, in the Religion within the Boundaries of Mere Reason, he seems to express a completely different opinion:

So far, as morality is based on the conception of the human being as the one who is free, but who also, just because of that, binds himself through his reason to unconditional laws, it is in need neither of the idea of another being above him in order that he recognize his duty, nor, that he observe it, of an incentive other than the law itself. (...) Hence on its own behalf morality in no way needs religion (...) but is rather self-sufficient by virtue of pure practical reason (RGV, AA 06:3).

I interpret the above-quoted passage from the first-edition Preface literally, bearing in mind particularly the limitation of pure rational religion which the title of the work announces. Kant does not claim that ethics needs no religion at all; it does not need religion only to know the duty, to have a motive to obey it. However, duty and its observance are not enough for a person (KpV, AA 05:25) who is not only a free and rational being but also a natural one (cf. also KpV, AA 05:88, 158-159). While ethics itself does not require religion, a rational and sensible being such as a human who is capable of moral behavior (and appreciates it) needs religion in order to identify being as moral as possible with being happy. ${ }^{3}$ It seems that in the Critique of Practical Reason the emphasis is placed on

\footnotetext{
${ }^{2}$ I cite fragments of Kant's writings according to the English edition (The Cambridge Edition of the Works of Immanuel Kant, P. Guyer, A.W. Wood (eds.), 16 vols, Cambridge University Press, Cambridge: 1992-2016), but the volume and page numbers are provided according to the German one: Kants gesammelte Schriften, The Royal Prussian, subsequently German, then Berlin-Brandenburg Academy of Sciences (ed.), 29 vols, Georg Reimer, subsequently Walter de Gruyter \& Co., Berlin: 1900-.

${ }^{3}$ John E. Hare recalls the interpretation proposed by Anthony Clifford Grayling in The Gifford Lectures in this way (Hare (2011): 163).
} 
fulfilling man's need for happiness as a natural being. ${ }^{4}$ By contrast, in the Religion within the Boundaries of Mere Reason, the emphasis is rather on the limitations of man as a moral being, arising from his tendency to evil. In the face of this obstacle, the very fulfilment of moral goals becomes unattainable. ${ }^{5}$

A characteristic feature of Kant's ethical conception is the immutability of the manner in which it justifies moral conduct. The good will is solely determined by the moral law. ${ }^{6}$ Nevertheless, Kant's late works, in particular, provide a different perspective on the relationship between ethics and religion. Jakub Sirovátka believes that understanding this relationship is helped by the allegory of the sun, which Kant used in his treatise On a Recently Prominent Tone of Superiority in Philosophy (VT, AA 08:399). ${ }^{7}$ Kant thereby introduces a hermeneutical key that helps us understand how a transcendent idea may offer man direction in practical life. ${ }^{8}$ Although Kant invariably maintains in his writings of the 1790s that it is not possible to know God theoretically, he also holds that the moral law, which is all that is 'supersensible within us', allows us to conceptualize what is 'supersensible beyond $\mathrm{us}^{\prime} .{ }^{9}$ It can be said that it is only through the moral law that the 'supersensible beyond us has become visible'. ${ }^{10}$ The 'practical reality' of God and the immortal soul (MS, AA 06:253; KU, AA 05:456; RGV, AA 06:5-6) ${ }^{11}$ as postulates of practical reason do not imply some new form of existence. Rather, it is the only possible perspective from which they are 'visible' as something that is given and not as something that is merely a product of the creativity of the human mind. This also allows us to see in a different way the relationship between pure rational religion and historical faith. Pure rational religion is the only perspective that can protect the content of historical faith from being interpreted in fantastical ways.

The limitations of human nature create a genuine obstacle to the high demands of practical reason. This is why a systematic and consistent consideration of morality with its premises, on the one hand, and its consequences on the other, leads to the 'practical necessity' (GMS, AA 04:414, 434) of believing in the existence of all the conditions necessary for the realization of the moral world in the sensible world. Kant's intention is to show that, if we want to think about morality in a systematic and consistent way, we must arrive, inter alia, at a practical-moral belief in the existence of God as a being beyond ourselves. ${ }^{12}$ If I may use such a phrase here, the 'guardian' of that 'beyond us' is in some sense historical faith. The believer certainly assumes that God really exists, even if it is obvious to him that he cannot know this in a theoretical-objective sense. Such

\footnotetext{
4 "We are free and we are natural beings. To the extent that we are free we are like God, who has no need of an idea of a God over Godself or of an incentive other than the moral law itself. But to the extent that we are also natural beings, we desire our own happiness in everything else that we desire, and we need the practical postulate of God to bring that happiness together with morality for us and for everyone" (Hare (2011): 165).

${ }^{5}$ Palmquist (1992): 141.

${ }^{6}$ Sirovátka (2019): 57.

7 Ibidem: 68.

8 Ibidem: 69.

${ }^{9}$ Ibidem: 70.

${ }^{10}$ Ibidem: 71.

${ }^{11}$ Cf. Eisler (1994): 432.

12 Sirovátka (2019): 72.
} 
faith cannot be regarded merely as a product of reason. But if one were to regard one's own belief in God merely as a product of one's own reason, then one would be deceiving oneself. Kant rejects such a possibility. The man who in his whole life is guided by the moral law, and at the same time wishes to regard his pursuit of the good as a rational project, must also believe in the reality of what practical reason presents to him as the object of faith. ${ }^{13}$ I realize that Sirovátka's argumentation is directed mainly against those interpretations of Kant's Opus postumum which identify God with practical reason. However, this does not change the fact that the argumentation also strengthens the position of Stephen R. Palmquist and other proponents of defending the status of historical faith in Kant's philosophy of religion.

For this reason, Palmquist objects to the understanding of Kant as an opponent of historical faith (empirical religious tradition) and proposes to go beyond the traditional narrow deontological interpretation of Kant's philosophy of religion which is often reduced to a purely formal moral theory. ${ }^{14}$ In a positive way, historical faith can be understood as either a mere carrier of true religion or a necessary means of moral empowerment. The latter case is considered by Palmquist as a real value of historical faith. At the beginning of Religion, Kant rules out the dependence of ethics on religion if it is to be based on the idea of a higher-than-human being as the source of our knowledge about duty and the motives for obeying it (RGV, AA 06:3). In other words, the awareness of the law (GMS, AA 04:401,410,427) is sufficient for moral motivation and we do not need to add the authority of the legislator (God). This does not mean that we do not do so (MS, AA 06:487), nor that, as Palmquist suggests, such an 'additional' presentation, placed 'beyond' or even 'above' the presentation of the law is not a 'reinforcement' of it. ${ }^{15}$ Palmquist is right in asserting that this 'reinforcement' is 'a necessary means'. ${ }^{16}$ The adoption of historical faith is treated by Palmquist as a prudential move in the project of Kant's philosophy of religion, which protects against a rigorous understanding of Kant's ethical formalism.

I share Palmquist's determinations regarding historical faith in Kant's system of philosophy of religion. However, I would like to complement Palmquist's analysis and highlight the potential of historical faith as a source of practical ideas, which can serve to supplement what Kant calls 'theoretical deficiencies' in The Conflict of the Faculties. I will first outline the ordinary moral consciousness that typically exists as historical faith before indicating the reasons that led Kant to include historical faith in the system of philosophy of religion. These can be summarized as what commentators on Kant's philosophy call the 'moral gap'. Finally, I will draw attention to the way in which historical faith fills this 'moral gap'. For the believer, the content of historical faith is not

\footnotetext{
${ }^{13}$ Ibidem: 74-75.

14 Palmquist (1992): 129-131; cf. Palmquist (2015a): 74.

${ }^{15}$ In Kant's definition of religion, this 'weakening' of the relationship between the moral law and the legislator (God) is expressed by the term 'as' ('instar'). The presentation of the moral law as a divine command - let us use the analogy to the famous imaginary "[a] hundred actual dollars" ( $\mathrm{KrV}$ A 599/B 627) - adds nothing to the actual presentation of the law. The presentation of the law will remain a mere representation even if we add an imaginary actual cause to it, just as the depicted God will remain a depiction, even if we imagine Him as existent.

16 Palmquist (2015a): 57, 67; cf. Kupś (2018).
} 
merely a way of conceiving of his own life as a systematic whole, but an actual solution to the disproportion between his limitations as a natural being and the goals that practical reason sets before him. The unbeliever, on the other hand, will find practical ideas in historical faith which can be used to fill the theoretical gap in the picture of his own life.

\section{Ordinary Moral Consciousness}

Let me first explain why I believe that historical faith is an essential part of ordinary moral consciousness. Although historical faith has often been credited with the potential to justify morality, Kant utterly rules out this understanding of the relationship between historical faith and morality. It seems that Kant would agree that historical faith can make the picture of human life more coherent. This function of historical faith is not only important but proves to be essential for practical philosophy.

In his essay entitled Ethics, Leszek Kołakowski expressed his belief in the close relationship between religion and ethics in the following way: "Moral rules, including the concept of sin and merit, clearly form a part of all known human societies. At a certain stage they usually merge with religious beliefs ... in highly developed religions, all the moral commandments appear in a religious context." ${ }^{17}$ I understand Kołakowski's statement literally, namely as a description of the relationship between pure rational religion (here: 'moral commandments') and historical faith (here: 'religious context'). Kołakowski describes this relation in a manner similar to Kant, namely by means of the metaphor of concentric circles (RGV, AA 06:12), as an opposition between the center and periphery. ${ }^{18}$

This 'religious context' expresses - often vaguely and metaphorically - an 'ordinary moral consciousness'. The fact that this 'context' is peripheral in relation to the 'center' does not make it irrelevant. On the contrary, I want to think of this 'context' as a basis which inspires the formulation of certain moral rules. This basis, which may have

\footnotetext{
${ }_{17}$ Kołakowski (1994): 6. Kołakowski's understanding of "highly developed religions" is similar to that of Michael Dummet, i.e., based on a common moral consciousness, in which moral living is a necessary condition of salvation (Dummet (2010): 47).

${ }_{18}$ On the controversy over the German translation of the term Grenzen used in the title and the resulting differences in the interpretation of Kant's position see: Palmquist (1992): 132-133; Palmquist (2016): 32-34. Palmquist accuses translators of neglecting the meaning of the metaphor of concentric circles by the unfortunate use of the term 'limits' in the title (cf. Kant (1934)) and even of imposing an interpretation of Kant's philosophy of religion in the spirit of moral reductionism, which is contrary to his interpretation. Palmquist believes that Kant did not intend to introduce an exclusionary restriction that would result in the complete questioning of everything that cannot be recognized as pure rational religion. In fact, the metaphor of concentric circles suggests 'overlapping' rather than 'neighbouring'. This means that "religion based on revelation may contain much (or even all) of the inner core (i.e., what reason tells us religion ought to be), but its historical grounding means that it will inevitably include other material not strictly required by reason in its unclothed, bare (blosen) state" (Palmquist (2016): 33). Cf. Feloj (2011). With the use of the symbol of concentric circles, unpublished versions of the foreword represent the relationship between reason and the Bible, and their ranges as explicitly excluding (ausschließenden), eccentric (excentrischer) (cf. VARGV, AA 23:95). In the final version of the preface, Kant abandoned this interpretation. This means that also in further interpretations of Kant's text we have the right to omit 'excluding' (eccentric) interpretations, and in case of any doubt, put the emphasis on the 'including' (concentric) interpretation.
} 
been expressed in the past more than today in the commonly accepted beliefs of a particular religious tradition, always manifests itself as a commonly held value horizon. ${ }^{19}$ What I have called here a 'value horizon' and, following Ronald Green, 'deep structure', ${ }^{20}$ would be equivalent to what Max Scheler calls the principle of value preference, ${ }^{21}$ and what I identify as the sphere of the 'dormant' practical ideas ${ }^{22}$ remains hidden in the historical faith.

This does not mean, however, that the basis for the system of value preference is unreasonable; on the contrary, as Leszek Kołakowski says,

without the belief that the distinction between good and evil depends neither on the arbitrary decisions of the individual nor on the political conditions of the moment, and that this distinction cannot be traced back to the distinction between the helpful and the harmful, our civilization will be lost. And Kant made the most important and forceful attempt to substantiate the irreducibility of this distinction as a matter of reason, not as a matter of revelation (Kolakowski (1997): 48).

In Kant's philosophy of religion, the appeal to the ideas stored in the historically defined religious tradition is not unreasonable. On the contrary, it is an expression of deeply rooted, albeit usually 'dormant', rationality. ${ }^{23}$

Historical faith in Kant's philosophy is precisely such an implicit basis to which pure rational religion refers. I consider historical faith to be part of what Alasdair MacIntyre calls ordinary moral consciousness. ${ }^{24}$ Historical faith is not the only element, but one among many, of what may be called ordinary moral consciousness, and which makes up the general conditions under which moral dispositions are awakened. For Kant, the source of moral consciousness is primarily the Christian religious tradition, ${ }^{25}$ but this does not mean that Kant justifies morality by Christian revelation. What I mean by ordinary moral consciousness is an awareness that is neither produced nor chosen, ${ }^{26}$ in this sense it is 'the fact of reason' (KpV, AA 05:31; cf. also KpV, AA 05:47). In this case, I understand historical faith as an essential component of a maximalist ethics, but I do not regard it as a condition of morality: "Historical faith is 'dead, being alone,' i.e.,

\footnotetext{
${ }^{19}$ Jacobs (2012): 66.

${ }^{20}$ Green (1978): XI. Green uses these terms by analogy with Noam Chomsky's linguistic theory, which contrasts "deep structure" and "surface structure". Cf. Firestone and Jacobs polemic (Firestone, Jacobs (2007): 70).

21 'A 'morality' is a system of preference between the values themselves, a 'moral constitution' which must be discovered behind the concrete valuations of a nation and an era" (Scheler (1972): 59).

${ }^{22}$ Firestone, Jacobs (2007): 68.

${ }^{23}$ Green (1978): 16.

${ }^{24}$ MacIntyre (1998): 122.

${ }^{25}$ First of all, it is pietist Lutheranism (Borowski, Jachmann, Wasianski (1912): 162-163; Arnold (1908)).

${ }^{26}$ I understand it similarly to Roger Scruton (Scruton (2014): 14). What has not been chosen is first and foremost tradition, but also what is independent of tradition and yet 'is given'. It seems that Kant considers duty in this way. In such a case, tradition would be one of the possible ways in which an obligation can be given. 'The fact of reason' means "the source experience of being obliged to something" (Krämer (1992): 14; cf. Hare (2011): 151; Fischer (2014): 49 and subsequent articles). 'The fact of reason' has the same status in practical philosophy as the reality of scientific cognition (Newtonian physics) in theoretical philosophy.
} 
of itself, considered as declaration, it contains nothing, nor does it lead to anything that would have a moral value for us" (RGV, AA 06:111; cf. also SF, AA 07:66-67). Therefore, I believe that Kant's critical statements about what is historical in religion are only directed against the heteronomous motivation of the will and the derivation of duty from examples: "What is historical serves only as an illustration, not as evidence" (SF, AA 07:437, note). Historical faith provides the ideas necessary to think of ethics as a coherent system (i.e., as rational), under the conditions of given ordinary moral consciousness. ${ }^{27}$ Because the above-mentioned consciousness includes, on the one hand, the deficits of imperfect human nature (radical evil), and on the other - high moral requirements (the highest good), this coherence is aimed at completing the 'moral gap'. ${ }^{28}$ However, this complementation is transcendental rather than metaphysical. ${ }^{29}$

Ordinary moral consciousness is crystallized around ideas ( $\mathrm{KrV}$ A 468/ B 496; cf. $\mathrm{SF}, \mathrm{AA} 07: 9)^{30}$ which, apart from the practical use of reason, are not only unnecessary but can even be harmful (Prol, AA 04:331). They only make sense in the systematization of ordinary moral consciousness, complementing the theoretical deficiencies resulting

${ }^{27}$ The detailed requirements of historical religions only confirm that they must have been preceded by 'ordinary moral consciousness'. Primitive tribal religions 'control' the conduct of their community members in much more detail and with much more ruthlessness than the monotheistic systems of Bible-based religions do. I assume, therefore, that religion as a system of regulation and control of human activity is the oldest form of 'ordinary moral consciousness'. I also assume that what is important is not what principles the system adopts (they are undoubtedly relative), but the very fact of thus introduced heterogeneity (the opposition 'good vs. bad'; or what Mircea Eliade describes as the opposition of the 'sacred vs. profane', etc.). I think that the dispute lies precisely with this fundamental assumption: 'not everything is allowed.' I also assume that this first assumption is at the heart of every historical faith. I do not claim that only religion adopts it (chess players also assume that 'not everything is allowed'). However, I do claim that religion accepts this assumption in a primitive, archetypical way.

${ }^{28}$ This term was used by John E. Hare to describe the assumptions of modern moral philosophy. The overriding requirement of morality, as Hare believes, is that everyone should be as interested in others as we are in ourselves. But since we cannot think and act in this way on our own, there is a need for some 'at least possible being' who, as the ultimate source of authority, places and fulfils this moral demand. 'The moral gap' is what Hare calls the inevitable distance between what we really can and what we should think and do (Hare (2011): 159-160; cf. Hare (1996)). In one of the lectures, Kant speaks directly about the fact that religion complements (komplettiert) morality, thus permitting the combination of virtue and happiness (V-PP/Powalski, AA 27:164).

${ }^{29}$ The 'addition' is 'transcendental' in the sense that it only provides possible (i.e., conceivable) conditions to justify moral behavior. However, it does not determine the objects of these intelligibilia. If such a resolution was made, this 'addition' would not have purely formal, but material character, and therefore would be 'metaphysical'. When writing about the 'transcendental addition', I do not claim that historical faith is an important addition to transcendental philosophy. At the time of the publication of the Critique of Pure Reason, Kant did not foresee all the consequences of his philosophical project. He began to develop his practical philosophy as a result of polemics and reviews. In turn, within practical philosophy, he modified, changed, and radicalized his position. I consider the use of the expression 'transcendental' in relation to the meaning of 'addition' in religion justified due to Kant's general attitude to seek, after the Critique of Pure Reason, an answer to the question about the conditions of possibility. In this case it would be an answer to the question 'how is it possible to act morally?', which does not decide 'metaphysically' about the existence of conditions for moral conduct, but 'transcendentally' about the possibility of thinking of a justification based on certain conditions. Kant's discussion of space in the second edition of the Critique of Pure Reason is the source of the distinction I use here ( $\mathrm{KrV} \mathrm{B} \mathrm{38,} \mathrm{40).}$ ${ }^{30}$ Cf. Klemme (2004): 106. 
from people's rational and sensible nature, the limitations of their powers and maximalist aspirations and expectations. ${ }^{31}$ With such assumptions, a person is exposed to failure which he or she cannot overcome by him- or herself. . $^{32}$ The conditions of human life which lie 'beyond' the possibility of one's choice (limitations of human nature in the face of high responsibilities) induce people to seek help 'beyond' themselves. The metaphor of concentric circles is represented by the 'beyond' as a 'further sphere of faith' in relation to which pure rational religion seems to be merely an island "surrounded by a broad and stormy ocean, the true seat of illusion, where many a fog bank and rapidly melting iceberg pretend to be new lands" (KrV A 235/B 295)..$^{33}$

Instead, one should ask oneself what makes one decide to take a risk, to go beyond the faultless indications of reason and to seek solutions suggested by vague metaphysical ideas. An important motive which prompts one to take such a step may be helplessness in the face of the disproportion between the limitations of man as a natural being and the high aims set for him in the moral sphere.

\section{The Moral Gap}

In this section I will indicate the reasons that led Kant to include historical faith in his system of philosophy of religion. I will refer to the contemporary debate on Kant's philosophy of religion, which considers, among other things, that historical faith fills a 'moral gap' in Kant's system of practical philosophy.

The religious considerations in Kant's writings are correlated with the issues of evil. ${ }^{34}$ The Religion not only begins with reflections on radical evil in human nature,

\footnotetext{
31 "Reason, conscious of its impotence to satisfy its moral needs, extends itself to extravagant ideas which might make up for this lack, though it is not suited to this enlarged domain. Reason does not contest the possibility or actuality of the objects of these ideas; it just cannot incorporate them into its maxims of thought and action. And if in the inscrutable field of the supernatural there is something more than it can bring to its understanding, which may however be necessary to make up for its moral impotence, reason even counts on this something being made available to its good will even if uncognized, with a faith which (with respect to the possibility of this something) we might call reflective, since the dogmatic faith which announces itself to be a knowledge appears to reason dishonest or impudent: for to remove difficulties that obstruct what stands firm on its own (practically), when these difficulties touch upon transcendent questions, is only a secondary occupation (parergon)" (RGV, AA 06:52).

32 "... a need of pure practical reason is based on a $d u t y$, that of making something (the highest good) the object of my will so as to promote it with all my powers; and thus I must suppose its possibility and so too the conditions for this, namely God, freedom, and immortality, because I cannot prove these by my speculative reason, although I can also not refute them" (KpV, AA 05:142). Cf. Hare (2011): 156; Palmquist (2015a): 64.

33 Although Kant does not write about it directly, in my opinion, there exists an analogy between the metaphor of concentric circles and the metaphor of an island surrounded by the ocean. The first one is used by Kant in practical philosophy, the second one - in the theoretical. In functional terms, however, they express the relationship between the certain (clear) and the uncertain (unclear). Cf. Feloj (2011): 39. ${ }^{34}$ Religion as a way of understanding duties as divine commands presupposes a reasonable faith (trust), based on two foundations. The first is the doctrine of the postulates of practical reason (and the expectation of happiness contained therein), while the second is the doctrine of evil (and helplessness against its immensity and inevitability). Cf. Jacobs (2012): 63. Wilhelm G. Jacobs' article appeared only in a Polish translation. The paper was originally delivered during the conference "The Significance of Kant's Philosophy of State and Law" organized by the Institute of Philosophy of the University of Lodz on September 25-27, 2010.
} 
but even "can seem like a philosophical defence of the Christian idea of original sin." 35 Whereas in fact "Kant's aim in this book is not to defend the doctrine of original sin, but rather precisely to exclude that from the portion of Christianity that can survive the scrutiny of pure reason." ${ }^{36}$ For this reason, the goal of the Kantian philosophy of religion is defined adequately by Palmquist in the following way: "The proper task of religion is to empower us to overcome this universal propensity to evil by influencing how we motivate ourselves to act." ${ }^{\prime 37}$ The definition, however, is correct on condition that we will understand 'influencing how we motivate ourselves to act' as encouragement to undertake moral motivation in general, not as specific motivation to undertake a specific action. ${ }^{38}$

If we consider Kant's early reflections on religion and ethics, and if we take into account the critique of rational theology, we find that it seems difficult to explain that there is a strongly present tendency in Kant's writings of the 1790s to affirmatively present the relationship between ethics and theology. ${ }^{39}$ The juxtaposition of theology and ethics in Kant's philosophy in the spirit of eliminative reductionism seems untenable in the long run, ${ }^{40}$ although this position still finds its adherents. ${ }^{41}$ Even if Kant does not reduce religion to ethics in an eliminative way, and does not regard religion as some 'definite form of morality,' he nevertheless holds that morality is 'teleologically incomplete, ${ }^{\prime 2}$ because it sets before rational beings an aim that cannot be realized by relying on a supposedly independent morality. There must therefore exist some possibility of a holistic view of this protracted and never completed process. Such an eschatological perspective is offered precisely by historical faith. Thus, if the need to relate ethics to religion arises in Kant's writings of the 1790s, it is probably mainly due to the confrontation of the moral purpose with the reality of evil, rooted in human nature, much deeper than Kant initially assumed. Religion fills the 'gap' between the theoretical (theology) and the practical (ethics), and thus makes Kant's philosophical project more plausible. ${ }^{43}$

The dependence of ethics on religion assumed by Palmquist seems to result from a confrontation with the reality of evil rooted in human nature and an attempt to make the philosophical project more realistic. Man reveals a 'radical attraction to evil', i.e., everyone is capable of doing evil in every situation, not only under certain extreme conditions: "Nor is it necessary to assume that these are sunk into evil and are examples that lead him astray: it suffices that they are there, that they surround him, and that they are human beings, and they will mutually corrupt each other's moral disposition and

\footnotetext{
${ }^{35}$ Guyer (2006): 226.

${ }^{36}$ Ibidem.

37 Palmquist (2015a): 65.

${ }^{38}$ Klemme (2004): 118.

${ }^{39}$ In the 1970s this way of interpreting Kant's philosophy of religion was represented among others by Allen W. Wood and Michel Despland. The contemporary proponents of this interpretation are, inter alia, Stephen Palmquist and Chris Firestone. I do not discuss this current here, but only point out possible alternative ways of interpreting the relation between ethics and theology in Kant's philosophy. 40 Palmquist (1992): 129.

${ }^{41}$ Staeps (1907): 105; Cassirer (1921): 407; Edwards (1979): 46. In Poland, the chief proponent of this interpretation is Maciej Chlewicki, although he understands the thesis "morality is religion" as "the elevation of ethics to the rank of religion" (Chlewicki (2012): 137).

42 Palmquist (1992): 134.

${ }^{43}$ Ibidem.
} 
make one another evil" (RGV, AA 06:94). This sad finding leads Kant to accept the support of the moral progress of humanity which he places in the order of religious ideas: "even with the good will of each individual, because of the lack of a principle which unites them, they deviate through their dissensions from the common goal of goodness, as though they were instruments of evil, and expose one another to the danger of falling once again under its dominion" (RGV, AA 06:97).

For reason, operating in accordance with the "presentation of rights" (GMS, AA 04:401, 410,427), the 'only presented' idea of God is also a sufficient wake-up call. ${ }^{44}$ Reason does not have to assume any (physical) force. It only assumes 'presented force' (that which is intelligible itself can only be 'stimulated' by that which is intelligible). In the order of concepts, only a concept can 'work' effectively. Such a concept is indeed the idea of God. ${ }^{45}$ All the subsequent definitions of religion ${ }^{46}$ give answers to the questions raised in the Dreams of a Spirit-Seer, Illustrated by Dreams of Metaphysics: "Does not the heart of man contain within itself immediate moral prescriptions? Is it really necessary, in order to induce man to act in accordance with his destiny here on earth, to set the machinery moving in another world?" (TG, AA 02:372). The man motivated in his actions by the duty of moral law seems to be only 'as if' moved by the force of machinery from the other world. The relationship between the man and the moral law (God's command) is a certain modal relationship (as if - instar), not an outwardly causal relationship. People refer to the moral law within themselves, 'as if' it were the divine law. The foundation of this relationship is contained in the imperative itself. 'God' is not a substance 'beyond

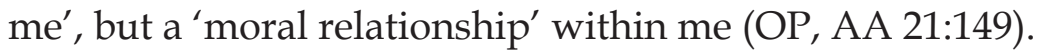

Making the moral law ('God's voice') out of the law, we imitate God's competence when we are guided in our own actions and issue moral judgements (of guilt and innocence) (KpV, AA 05:80; OP, AA 22:64). But we cannot do so in the case of God's prerogative as the ruler of the world - one cannot create a world in which everything would happen according to one's own will. ${ }^{47}$ At the end of the third part of Religion, Kant - in addition to the above-mentioned need to unite people - identifies another unattainable goal, namely happiness:

Since by himself the human being cannot realize the idea of the supreme good inseparably bound up with the pure moral disposition, either with respect to the happiness which is part of that good or with respect to the union of the human beings necessary

${ }^{44}$ Particularly in Opus postumum: "There must also, however, be - or at least be thought to be - a legislative force (potestas legislatoria) which gives these laws emphasis (effect) although only in idea; and this is none other than that of the highest Being, morally and physically superior to all and omnipotent, and His holy Will - which justifies the statement: There is a God" (OP, AA 22:126). Cf. also: OP, AA 21:20; OP, AA 22:52, 53.

45 "God is not a creature beyond me, but only an idea within me" (OP, AA 21:145). Cf. also: OP, AA 21:148; OP, AA 22:126; KrV A 577-578/B 605-606. A sufficient condition is the mere possibility of thinking of the highest moral authority ("only in an idea"). Its existence or non-existence does not matter at all. Cf. Kupś (2016): 234 ff.; Tomaszewska (2020).

46 "Religion is (subjectively considered) the recognition of all our duties as divine commands" (RGV, AA 06:154). Cf.: KpV, AA 05:130; KU, AA 05:481; MS, AA 06:443, 487; SF, AA 07:36; OP, AA 21:74; OP, AA 22:53, 118.

${ }^{47}$ Hare (2011): 157. Cf. Jacobs (2012): 63. 
to the fulfilment of the end, and yet there is also in him the duty to promote the idea, he finds himself driven to believe in the cooperation or the engagement of a moral ruler of the world, through which alone this end is possible. And here there opens up before him the abyss of a mystery regarding what God may do, whether anything at all is to be attributed to Him and what this something might be in particular, whereas the only thing that a human being learns from a duty is what he himself must do to become worthy of that fulfilment, of which he has no cognition or at least no possibility of comprehension (RGV, AA 06:139).

'The abyss of a mystery' is an expression Kant applies to describe what Hare expresses by the 'moral gap', i.e., the enormous disproportion between what I myself know that I must and can do to develop the idea of the highest good and what else is needed in order to put this idea into reality. However, he does not deal with historical faith as a source of trust in the 'divine supplement' ${ }^{\prime 8}$ that complements human agency. Historical faith is only a source of ideas I can use to think of my life as not being doomed to inevitable failure.

One's moral effort is always incomplete and unfinished in relation to the requirements of the highest good. The fulfilment of this deficiency must therefore be based only on the belief that such an undertaking is possible, i.e., a number of assumptions that make this goal attainable must be taken into account. ${ }^{49}$ But such 'attainability' means nothing else but the attainability which can be thought of. 'The moral gap' in the moral system presented by Kant is understood by Hare as the difference between what a human being is and what requirements he or she has to satisfy. The requirement, or 'ought', is shown as something potentially real, as 'can'. The question arises whether it is possible to fill this gap by a 'divine supplement'. Or is it only conceivable under certain conditions (Kant calls it the 'postulates of practical reason'), i.e., by adopting a model in which the idea of God describes the power that makes what man cannot achieve and what must be rationally assumed as part of the structure for fulfilling the moral obligation?

In this case, 'assistance' refers to the fulfilment of happiness, ${ }^{50}$ which is proportional to the moral competence that a person achieved with his/her own effort (i.e., they became worthy of happiness). So, the point is only to think of the 'available help' as one of the necessary conditions for the fulfilment of moral obligations. In this way, as Hare claims, Kant resolves the contradictions between 'ought' and 'can'. ${ }^{51}$

\footnotetext{
${ }^{48}$ Hare (1996): 38 and subsequent articles.

49 "We need to believe in effects of grace in order to see how we can live under the moral law" (Hare (2011): 152).

${ }^{50}$ Hare does not write about happiness, but about the 'good' which he distinguishes from the 'moral

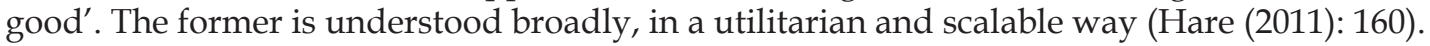

${ }^{51}$ Hare (2011): 160. Alasdair MacIntyre is of a similar opinion: "I become aware of it as a set of precepts which in prescribing to myself I can consistently will should be obeyed by all rational beings. The test of a genuine moral imperative is that I can universalize it - that is, that I can will that it should be a universal law, or, as Kant puts it in another formulation, that I can will that it should be a law of nature. The point of this latter formulation is to stress that not only must I be able to will that the precept in question should be recognized as a law universally, but I must also be able to will that it should be acted on universally - in the appropriate circumstances. The sense of 'be able to' and 'can' in these formulations is equivalent to 'can without inconsistency', the demand for consistency being part of the demand for rationality in a law that men prescribe to themselves as rational beings" (MacIntyre (1998): 123-124).
} 
The formulation of the necessary conditions for the fulfilment of the idea of the highest good only ensures the 'thinkability' of the model justifying a human action under certain conditions. However, it does not determine the existence of elements which make up its functional whole. In this model, it is not necessary to answer the question concerning the existence the God; what is required here is the fact that God is a conceived idea. ${ }^{52}$ And since theoretical reason, due to its own limitations, does not exclude the divine will, practical reason can refer to such an idea (cf. KrV B XXIX-XXX). "The reason we cannot make theoretical use of effects of grace is that they go beyond the limits of the understanding." 53 This 'beyond' corresponds to the metaphorical external circle of historical faith in revelation, in which the way grace works remains 'unclear' (i.e., not understood). ${ }^{54}$ Kant, as emphasized by John E. Hare, is in this respect influenced by the tradition of Augustine and Luther. ${ }^{55}$ However, in contrast with the thinking of Augustine or Luther, what we can do to make ourselves worthy of receiving the assistance contrary to what Hare claims ${ }^{56}$ - is clear and reduced entirely to moral obligation. Kant clearly shows this in his interpretation of the biblical story of the sacrifice of Isaac (SF, AA 07:63; cf. OP, AA 21:91, 142; OP, AA 22:64, 117).

The problem, however, is that even the mere capacity to act morally is not sufficient to meet moral ends. This is what Palmquist highlights in his interpretation of the Religion within the Boundaries of Mere Reason. While morality is sufficient for itself, it is not sufficient for human beings to achieve the goals of morality. Historical faith offers us ideas that enable us to conceive of our lives as fulfilled despite the limitations of our own nature and the conditions of the world. ${ }^{57}$

\section{'Dormant' Practical Ideas}

I intend to consider here the manner in which historical faith fills the 'moral gap'. However, my focus is not on the practical consequences of the believer's acceptance of the content of historical faith. For the believer, the content of historical faith is the actual resolution of the disproportion between his limitations as a natural being and the goals set for him by practical reason. Rather, I am interested in the theoretical potential of historical faith as a source of ideas for making the picture of human life more coherent.

\footnotetext{
${ }^{52}$ Förster (2000): 81 ff.; Kupś (2016): 248-275; cf. Vaihinger (1922): 666-667.

${ }^{53}$ Hare (2011): 160.

54 Jacobs (2012): 65.

${ }^{55}$ Hare (2011): 159.

${ }^{56}$ Ibidem: 161.

${ }^{57}$ It would be rather wrong to narrow down the understanding of the 'ideas' that I am referring to solely to transcendental ideas. An idea means, above all, also the idea of the supreme good (RGV, AA 06:5), which makes the Kantian system of morality real and thus in a way 'completes it'. It seems that Kant also attributes a similarly 'complementary' function to other practical ideas about which he does not write as clearly as he does about the idea of the supreme good, but which are nevertheless considered in the Religion. Assuming that the Religion (RGV, AA 06:52) and The Conflict of the Faculties (SF, AA 07:9) discuss the same issue, we could add to the list of 'morally transcendent' ideas (RGV, AA 06:53) the religious idea of the source of the moral evil, where "[t]he absolutely first beginning of all evil is thereby represented as incomprehensible to us" and the religious idea of "hope of a return to the good from which [one] has strayed" (RGV, AA 06:44).
} 
One might say that the non-believer finds in historical faith practical ideas that allow him to fill the theoretical gap in the picture of his own life even if the ideas do not influence practical dimension of the believer's life.

There is always a dissonance (the 'moral gap') between the reality of human life (character traits and gifts of fate) and the moral obligation, but it is 'visible' only under the specific conditions of a pure model. ${ }^{58}$ Kant does not describe real human behavior; instead, he creates a model by which it can be described. ${ }^{59} \mathrm{I}$ believe that the historical faith in Kant's project of philosophy of religion is intended to actually help one in this task, but it does so only in the case of a true believer, for whom practical ideas are not mere fictions to make the overall picture of his own life more coherent. In other words, religion does not say how the 'moral gap' ceases to exist, but what I have to assume to think of such a goal as possible to achieve. ${ }^{60}$ Radical evil in man does indeed make the achievability of the moral ends questionable. Palmquist is certainly right when he concludes on this basis that "we need more than mere morality." 61 This something 'more' must therefore simply lie outside 'morality itself', in what Kant metaphorically described as the outer circle of historical faith. From this faith we derive the ideas that allow us to imagine the goals of our lives as attainable. Palmquist stresses, however, that according to Kant, the use of the content of historical faith must always be subordinated to the priority of morality. ${ }^{62}$ For instance, "doing good works - trying to live a good life - is the rational basis upon which we can conceive of ourselves as having received God's grace."63

The interpretations of Kant's philosophy of religion in the spirit of moral reductionism may have negative consequences for historical faith. However, it is not obvious that Kant would actually agree to all of them. "A common misnomer about Immanuel Kant's philosophy is that his 'religious' vision looks forward to the eventual demise of all historical elements of faith (such as ceremonial practices, purported revelations, and ecclesial hierarchies) and the replacement of these elements with a moralist community that has, at best, a deistic belief in God." ${ }^{64}$ The authors of the article just quoted, Chris L. Firestone and Nathan Jacobs, point to Yirmiyahu Yovel ${ }^{65}$ and Allen Wood ${ }^{66}$ as the

\footnotetext{
${ }^{58}$ The criticism of Friedrich Schiller is only justified if it applies to the action of a living person in the real world. However, it does not refute the Kantian justification of the metaphysical source of moral behavior. Cf. Palmquist (2015a): 64-65. Cf. RGV, AA 06:23-24, note. Mikhail Bulhakov paraphrased Friedrich Schiller's polemic in his most famous novel (The Master and Margarita), in the words spoken by the editor: "it is not for nothing that Schiller says that Kant's considerations on this subject can only satisfy people with the souls of slaves." For a critical study of this literary paraphrase see Krouglov (2012): $323 \mathrm{ff}$.

59 'Model' (or 'description') does not replace the quid juris justification. The 'model' that I am talking about 'describes' this whole in which the justification (quid juris) of human behavior can only be formulated (as a part of the described whole).

${ }^{60}$ Unlike the moral obligation I know how to fulfil (RGV, AA 06:44), the way in which 'assistance' is to be given by such a being is completely beyond human understanding (RGV, AA 06:53). What 'I do not know' is an object of religious hope.

61 Palmquist (1992): 141.

${ }^{62}$ Ibidem: 138.

${ }^{63}$ Ibidem: 143.

${ }^{64}$ Firestone, Jacobs (2007): 63.

${ }^{65}$ Yovel (1980): 202.

${ }^{66}$ Wood (1991): 7.
} 
representatives of this stance. Historical faith is only treated by Yovel and Wood as something Kant either rejects directly or prophesies the disappearance of, as a result of the inevitable progress of history. In their analysis of the third part of the Religion, Firestone and Jacobs express a contrary opinion, namely that Kant not only attributed to the 'moral community' a much more solid theological foundation, but above all that "he does not see the moral doctrines or rational religion as something necessarily at odds with historical faith." ${ }^{67}$ I agree with this thesis. The absence of contradictions is an elementary condition of rationality. The absence of contradictions between historical faith and rational religion does not mean there is a causal relationship between them; at most, ideas taken from historical faith can be applied to confirm and complement pure rational religion. I think this is what Kant does in the Religion and in The Conflict of the Faculties.

Firestone and Jacobs point to the studies by Peter Byrne and Sharon Anderson-Gold as examples of the mitigation of divine authority over ethical community in the interpretation of the Kantian philosophy of religion. As a result of this approach, a kind of secular moral humanism is attributed to Kant "which has as its telos the eroding away of historical faiths in order to make room for the type of ethical society the moralists envisioned." ${ }^{68}$ But Kant announces nothing of that kind. His analyses of the ecclesiastical faith and historical religious denominations are critical, but not destructive to the historical faith, as Firestone and Jacobs claim. Kant does not look for causes of rational religion in historical faith; he rather seeks ideas to complement it. Worded differently, we do not know if the empirical religious tradition is necessary to shape certain higher moral institutions. Nevertheless, to understand how they are shaped, we need to involve in the explanation certain ideas held by historical faith.

Firestone and Jacobs think that Kant not only answers the question of "how a historical faith can become rational religion ... Kant's vision of this transformation process is not a simple replacement of history with morality. Instead, Kant's focus is on the role sacred history can play in awakening and establishing rational faith." 69 One aspect of Firestone's and Jacobs' interpretation in particular deserves our attention: it can be reconciled with my proposal to understand historical faith as a source of 'dormant' practical ideas which are necessary for the 'mature' man to understand his own situation (cf. WA, AA 08:35).

The uniqueness of the applicability of moral laws, as Kant writes in The Metaphysics of Morals, lies in the fact that they can be derived only from necessary and a priori grounds (MS, AA 06:215) and therefore cannot be justified by experience. The only conditions for the observance of the moral precepts are freedom and practical reason (MS, AA 06:216), irrespective of both the natural inclinations of man and any example of human behavior. Having metaphysics (or, in other words, grounds derived only from a priori concepts) is absolutely essential in this case: "a practical philosophy, which has not nature, but freedom of choice for its object, will presuppose and require a metaphysics of morals, that is, it is itself a duty to have such a metaphysics, and every human being also has it within himself, though as a rule only in an obscure way; for without a priori

\footnotetext{
67 Firestone, Jacobs (2007): 64.

68 Ibidem: 67.

69 Ibidem: 68.
} 
principles how could he believe that he has a giving of universal law within himself?" (MS, AA 06:216). Kant believes that the complement to the metaphysics of morality is provided by moral anthropology that reinforces moral principles with empirical means of education (MS, AA 06:217). We have reasons to believe that historical faith counts among these morality-enhancing empirical means. ${ }^{70}$

Historical faith undoubtedly stands out among the various means of moral anthropology. Historical faith is a particular 'obscure way' which, as Kant writes in The Conflict of the Faculties, merely complements "the theoretical deficiency which our pure rational belief admits it has (in the questions, for example, of the origin of evil, the conversion from evil to good, the human being's assurance that he has become good, etc.) and helps - more or less, depending on the times and the person concerned - to satisfy a rational need" (SF, AA 07:9). I understand the term 'theoretical deficiency' as a clear indication that ideas taken from historical faith do not fill the "gap" in the metaphysical order of things themselves, but they do provide practically sufficient answers that fill the existential gap that individuals face. In this way, Kant interprets the Christian soteriology based on hope for the absolution of sins and conversion to a new life in accordance with practical law (SF, AA 07:116). The complement in question is not metaphysical but transcendental.

\section{Conclusions}

Alasdair MacIntyre, summing up his assessment of Kant's doctrine of duty, highlights a certain indefiniteness and imprecision of practical law:

The doctrine of the categorical imperative provides me with a test for rejecting proposed maxims; it does not tell me whence I am to derive the maxims which first provide the need for a test. Thus the Kantian doctrine is parasitic upon some already existing morality, within which it allows us to sift-or rather, within which it would allow us to sift if the test it provided were a reliable test. Yet in fact it is not, even on its own terms. For the Kantian test of a true moral precept is that it is one that I can consistently universalize. In fact, however, with sufficient ingenuity almost every precept can be consistently universalized (MacIntyre (1998): 126).

I believe that Kant found a way to limit the production of maxims which can be effectively universalized. This limitation is the already existing morality, that is, what MacIntyre previously called 'ordinary moral consciousness' and what in Kant's doctrine of religion is called historical faith.

\footnotetext{
${ }^{70}$ Historical faith would be an instrument (Vehikel) leading to rational religion, or propaedeutics (organon) to 'pure moral faith' (RGV, AA 06:112; SF, AA 07:37, 42, 44, 45, 48, 50, 52). However, according to Firestone and Jacobs, Kant does not believe that "all historical faiths can, and do, bear the necessary seed of rational religion and serve as its vehicle" (Firestone, Jacobs (2007): 70). The arguments presented by Firestone and Jacobs come from Kant's critique of Judaism. For further discussion of the topic see: Palmquist (2015b); Vanden Auweele (2017).
} 
Another example of such a limitation of imagination by historical faith is provided by a small historiosophical dissertation from 1786 in which Kant attempts to sketch a presumed beginning of human history. ${ }^{71}$

Just for this reason, and since here I am venturing on a mere pleasure trip, I hope I may ask the favor to be allowed me to make use of a holy document as my map, and at the same time to imagine that my flight, which I make on the wings of the power of imagination, though not without a guiding thread attached by reason onto experience, might follow the same trajectory which that document contains in a historically prescribed manner (MAM, AA 08:109).

Kant's preparedness to limit the exaggerated claims of theoretical reason, ${ }^{72}$ cut the wings of exuberant imagination, ${ }^{73}$ or stifle the excessive aspirations of human cognition ${ }^{74}$ is perhaps - apart from thinking in terms of the opposites ${ }^{75}$ - the most characteristic feature of his critical philosophy. Here, I treat this limitation of imagination as an additional argument for my interpretation of the meaning of historical faith in the doctrine of rational religion.

Historical faith certainly 'complements' Kant's philosophy of religion from the perspective of aims. It is impossible, Palmquist notes, to reduce religion to morality without overlooking the nuances of the Religion within the Boundaries of Mere Reason. Morality is not self-sufficient, and religion is not just a 'hidden' morality. Rather, religion is a synthesis of the rational and the empirical. To 'make real' the foundations and aims of practical philosophy, we - metaphorically speaking - are required to clothe the 'naked body' of pure rational religion in the 'robe' of historical faith. ${ }^{76}$ Palmquist's insightful analyses allow us to see the 'complementary' function of historical faith from the perspective of aims, but at the same time they can distract us from a no less important fact, namely that historical faith itself in some way also limits our ability to imagine this 'complement'. Historical faith is first and foremost a legacy of a tradition offering ready-made, tested solutions. They remain at our disposal, but in the form of practical

\footnotetext{
${ }^{71}$ I am not so naive as to think that historical religion can be a source of principles. However, I do claim that reason in its freedom to create principles tends to be limited and that historical faith is a good limitation. I admit that my only point of attachment is Kant's interpretation of the text of the Bible, particularly the interpretation of Genesis contained in the Conjectural Beginning of Human History (1786). I do not treat Kant's interpretation as an example of using all the power of reason to find what is reasonable in what is historical (the rational nucleus hidden in the shell of superstition). Rather, I see it as an example that shows how reason fits into certain frames.

72 "Thus I had to deny knowledge in order to make room for faith" (KrV B XXIX-XXX).

73 "So far we have been wandering like Democritus, in empty space, whither the butterfly-wings of metaphysics have raised us, conversing there with spirit-forms. Now, when the styptic power of self-knowledge has folded those silken wings, we find ourselves back on the humble ground of experience and common sense ..." (TG, AA 02:368).

74 "It turned out, of course, that although we had in mind a tower that would reach the heavens, the supply of materials sufficed only for a dwelling that was just roomy enough for our business on the plane of experience and high enough to survey it ..." (KrV A 707/B 735).

${ }_{75}$ Brandt (2000): 179.

${ }^{76}$ Palmquist (1992): 132-133.
} 
ideas rather than pure concepts and rules. From a theoretical perspective we must treat them as something that is 'given' (revealed). And what is 'given' actually limits our imagination, not least when it comes to the way in which we 'complete' a moral concept from the perspective of aims. However, this seemingly negative effect has also positive consequences. The restriction of imagination by the content of historical faith, in terms of the way practical goals are formulated, protects us from the danger of turning practical philosophy into a completely arbitrary product of human creativity. ${ }^{77}$ The system of practical philosophy is not simply a product of imagination, whereas historical faith paradoxically proves to be the guardian of the autonomy of ethics.

\section{References}

Arnold E. (1908), “Kants Jugend und die fünf ersten Jahren seiner Privatdozentur im Umriss dargestellt", [in:] Arnold E., Gesammelte Schriften, vol. 3, O. Schöndörffer (ed.), Bruno Cassirer, Berlin: 108-210.

Borowski L.E., Jachmann R.B., Wasianski A.Ch. (1912), Immanuel Kant. Sein Leben in Darstellung von Zeitgenossen, Deutsche Bibliothek, Berlin.

Brandt R. (2000), "Die Krause-Papiere", [in:] Immanuel Kant und die Berliner Aufklärung, D. Emundts (ed.), Reichert, Wiesbaden: 179-189.

Cassirer E. (1921), Kants Leben und Lehre, Bruno Cassirer, Berlin.

Chlewicki M. (2012), Kant a problem filozofii religii, Wydawnictwo Uniwersytetu Kazimierza Wielkiego, Bydgoszcz.

Dummet M. (2010), The Nature and Future of Philosophy, Columbia University Press, New York. Edwards R.B. (1979), Reason and Religion, University Press of America, Washington.

Eisler R. (1994), Kant-Lexikon, Olms, Hildesheim-Zürich-New York.

Feloj S. (2011), "Metaphor and Boundary: H.S. Reimarus' Vernunftlehre as Kant's Source”, Lebenswelt 1: 31-46.

Firestone Ch.L, Jacobs N. (2007), "Kant on the Christian Religion", Philosophia Christi 9 (1): 63-72.

Firestone Ch.L, Jacobs N. (2008), In Defense of Kant's Religion, Indiana University Press, Bloomington.

Fischer N. (2014). "Zum Problem der Geschichtlichkeit in der Philosophie Kants. Eine Auslegung zum Bild der "konzentrischen Kreise" in Kants Religionsschrift", [in:] Kant und die biblische Offenbarungsreligion, N. Fischer, J. Sirovátka, D. Vopřada (eds.), Karolinum, Prague: 45-57.

Förster E. (2000), Kant's Final Synthesis: An Essay on the Opus Postumum, Harvard University Press, Cambridge-London.

Green R.M. (1978), Religion and Moral Reason: A New Method for Comparative Study, Oxford University Press, New York.

Green R.M. (2000), "Kant and Kierkegaard on the Need for a Historical Faith: an Imaginary Dialogue", [in:] Kant and Kierkegaard on Religion, D.Z. Phillips, T. Tessin (eds.), Macmillan Press, London: 131-152.

Guyer P. (2006), Kant, Routledge, London.

Hare J.E. (1996), The Moral Gap. Kantian Ethics, Human Limits, and God's Assistance, Clarendon Press, Oxford.

77 At this point, I interpret religion in a manner similar to Scruton's; see: Scruton (2010): 39-40. 
Hare J.E. (2011), "Ethics and Religion: Two Kantian Arguments", Philosophical Investigations 34 (2): 151-168.

Jacobs W.G. (2012), "Państwo i kościół w filozofii prawa Kanta", trans. M. Jagas-Chmielińska, M. Chmieliński, [in:] Aktualność i znaczenie historyczne filozofii państwa i prawa Immanuela Kanta, A.M. Kaniowski, T.W. Michałowski (eds.), Wydawnictwo Rolewski, Nowa Wieś k/Torunia: 62-70.

Kant I. (1766/1992), "Dreams of a Spirit-Seer Elucidated by Dreams of Metaphysics (1766)" trans. D. Walford, [in:] I. Kant, Theoretical Philosophy, 1755-1770, D. Walford (ed.), Cambridge University Press, Cambridge: 301-360.

Kant I. (1781/1787/1998), Critique of Pure Reason, trans. and eds. A.W. Wood, P. Guyer, Cambridge University Press, Cambridge.

Kant I. (1783/2002), "Prolegomena to Any Future Metaphysics that Will be Able to Come Forward as Science (1783)", trans. G. Hatfield, M. Friedman, [in:] I. Kant, Theoretical Philosophy after 1781, H. Allison, P. Heath (eds.), Cambridge University Press, Cambridge: $29-170$.

Kant I. (1784/1999), "An Answer to the Question: What Is Enlightenment? (1784)", trans. M.J. Gregor, [in:] I. Kant, Practical Philosophy, M.J. Gregor (ed.), Cambridge University Press, Cambridge: 11-22.

Kant I. (1785/1999), “Groundwork of the Metaphysics of Morals (1785)”, trans. M.J. Gregor, [in:] I. Kant, Practical Philosophy, M.J. Gregor (ed.), Cambridge University Press, Cambridge: $37-108$.

Kant I. (1786/2007), “Conjectural Beginning of Human History (1786)”, trans. A.W. Wood, [in:] I. Kant Anthropology, History, and Education, R. Louden, G. Zöller (eds.), Cambridge University Press, Cambridge: 160-175.

Kant I. (1788/1999), “Critique of Practical Reason (1788)”, trans. M.J. Gregor, [in:] I. Kant, Practical Philosophy, M.J. Gregor (ed.), Cambridge University Press, Cambridge: 133-272.

Kant I. (1790/2002), Critique of the Power of Judgment, trans. P. Guyer, E. Matthews, ed. by P. Guyer, Cambridge University Press, Cambridge.

Kant I. (1793/1996), "Religion within the Boundaries of Mere Reason”, trans. G. Di Giovanni, [in:] I. Kant, Religion and Rational Theology, A.W. Wood, G. Di Giovanni (eds.), Cambridge University Press, Cambridge: 39-216.

Kant I. (1796/2002), “On a Recently Prominent Tone of Superiority in Philosophy (1796)”, trans. M.J. Gregor, R. Anchor, [in:] I. Kant, Theoretical Philosophy after 1781, H. Allison, P. Heath (eds.), Cambridge University Press, Cambridge: 425-446.

Kant I. (1797/1999), "Metaphysics of Morals (1797)”, trans. M.J. Gregor, [in:] I. Kant, Practical Philosophy, M.J. Gregor (ed.), Cambridge University Press, Cambridge: 353-604.

Kant I. (1798/1996), “The Conflict of the Faculties”, trans. M.J. Gregor, R. Anchor, [in:] I. Kant, Religion and Rational Theology, A.W. Wood, G. Di Giovanni (eds.), Cambridge University Press, Cambridge: 233-327.

Kant I. (1934), Religion within the Limits of Reason Alone, trans. T.M. Greene; H.H. Hudson, Open Court Publishing Co, Chicago and London.

Kant I. (1993), Opus postumum, trans. E. Förster, M. Rosen, E. Förster (ed.), Cambridge University Press, Cambridge.

Kants gesammelte Schriften, The Royal Prussian, subsequently German, then Berlin-Brandenburg Academy of Sciences (ed.), 29 vols, Georg Reimer, subsequently Walter de Gruyter \& Co., Berlin: 1900-. 
Klemme F.H. (2004), Immanuel Kant, Campus, Frankfurt am Main.

Kolakowski L. (1997), Modernity on Endless Trial, trans. S. Czerniawski, W. Fries, A. Kolakowska, The University of Chicago Press, Chicago.

Kołakowski L. (1994), "Ethics", Dialogue and Humanism 4 (4): 5-41.

Krämer H. (1992), Integrative Ethik, Suhrkamp, Frankfurt am Main.

Krouglov A. (2012), Kant i kantovskaia filosofiia v russkoi khudozhestvennoi literature, Kanon, Moskva.

Kupś T. (2016), Opus postumum Immanuela Kanta, Wydawnictwo Naukowe Uniwersytetu Mikołaja Kopernika, Torun.

Kupś T. (2018), „,Religiöse Grundsätze politischer gemeiner Wesen (Kant und seine Fortführer)", Studia Philosophica Kantiana 2: 21-35.

MacIntyre A. (1998), A Short History of Ethics. A History of Moral Philosophy from the Homeric Age to the Twentieth Century, Routledge, London.

Palmquist S.R. (1992), “Does Kant Reduce Religion to Morality?”, Kant-Studien (83) 2: 129-148.

Palmquist S.R. (2000), Kant's Critical Religion: Volume Two of Kant's System of Perspectives, Ashgate, London.

Palmquist S.R. (2007), “Kantian Redemption: A Critical Challenge to Christian Views of Faith and Works", Philosophia Christi 9 (1): 29-38.

Palmquist S.R. (2015a), “Kant's Prudential Theory of Religion: The Necessity of Historical Faith for Moral Empowerment", Con-Textos Kantianos 1: 57-76.

Palmquist S.R. (2015b), “Kant's Lectures on Philosophical Theology - Training-Ground for the Moral Pedagogy of Religion?", [in:] Reading Kant's Lectures, R.R. Clewis (ed.), De Gruyter, Berlin/Boston: 365-390.

Palmquist S.R. (2016), Comprehensive Commentary on Kant's Religion within the Bounds of Bare Reason, John Wiley \& Sons, Chichester.

Scheler M. (1972), Ressentiment, L.A. Coser (ed.), trans. W.W. Holdheim, Marquette University Press, Milwaukee.

Scruton R. (2010), The Uses of Pessimism and the Danger of False Hope, Oxford University Press, New York.

Scruton R. (2014), The Soul of the World, Princeton University Press, Princeton.

Sirovátka J. (2019), Ethik und Religion bei Immanuel Kant. Versuch einer Verhältnisbestimmung, Karl Alber, Freiburg - München.

Staeps H. (1907), “Das Christusbild bei Kant”, Kant-Studien 12: 104-116.

Sudakov A.K. (2020), "Ob odnom novom podhode k interpretacii filosofii religii Kanta”, Voprosy Filosofii 10: 170-180.

Tomaszewska A. (2020), “Filozofia religii Kanta w kontekście nowożytnego racjonalizmu religijnego", Studia z Historii Filozofii 11 (1): 123-147.

Wood A.W. (1991), "Kant's Deism”, [in:] Kant's Philosophy of Religion Reconsidered, P.J. Rossi and M.W. Wreen (eds.), Indiana University Press, Bloomington \& Indianapolis, IN: $1-21$.

Vaihinger H. (1922), Die Philosophie des Als Ob, Meiner, Leipzig.

Vanden Auweele D. (2017), "Kantian Grace as Ethical Gymnastics", Con-Textos Kantianos 6: 285-301.

Yovel Y. (1980), Kant and the Philosophy of History, NJ: Princeton University Press Princeton. 